\title{
Peran Notaris Dalam Mendukung Investasi di Era Masyarakat Ekonomi ASEAN (MEA)
}

\author{
Ni Putu Mirayanthi Utami \\ ${ }^{1}$ Program Studi Magister Kenotariatan Fakultas Hukum Universitas Udayana, Bali-Indonesia \\ E-mail: mirayanthi.utami@gmail.com
}

\begin{abstract}
Info Artikel
Masuk : 31 Januari 2020

Diterima : 28 April 2020

Terbit : 30 April 2020

Keywords :

Notary, Investment, ASEAN

Economic Community (AEC),

Kata kunci:

Notaris; Investasi; Masyarakat Ekonomi ASEAN (MEA)

Corresponding Author: Ni Putu Mirayanthi Utami, E-mail: mirayanthi.utami@gmail.co $\mathrm{m}$

DOI :

10.24843/AC.2020.v05.i01.p03
\end{abstract}

\begin{abstract}
Indonesia is one of the ASEAN members who agreed to implement the ACIA which focuses on investment, as the result of the implementation of the AEC. With the expectation of increasing foreign investment activities between ASEAN member countries and becoming one of the investment destinations in the world. It is proven that Indonesia still the choice of foreign investors. In order to support interests of foreign investors in conducting their business, so the role of the Notary public in investment activities needed through written proof. This study aims to analyse and provide an understanding of the role of the Notary in supporting investment in Indonesia when the AEC is implemented. This research using normative juridical methods. The study results show that the role of the Notary through direct investment is authorized to make authentic deeds based on Company Law. Furthermore, the authority of the Notary is regulated in Notary Law and Notary Law Amandement such as: providing legal counselling, services and legalizing public documents that will be used in Indonesia or needed for investment abroad. The implication of AEC it would be awared by the Notary. Therefore as a profession in a field of law, the have a to provide a social services by mastering in English and knowledge able in investment of law accordance with hierarchy of legislation and increasing competence following Notary Law and Notary Law Amandement, Notary Ethics Code, and Bylaws I.N.I. so that they can compete professionally.
\end{abstract}

\footnotetext{
Abstrak

Indonesia merupakan salah satu anggota ASEAN yang menyetujui direalisasikannya ACIA yang berfokus pada investasi, sebagai implikasi diberlakukannya MEA. Dengan harapan dapat meningkatkan kegiatan investasi asing antara negara-negara anggota ASEAN dan menjadi salah satu tujuan investasi di dunia. Terbukti Indonesia masih menjadi pilihan investor asing. Guna menunjang kepentingan investor dalam menjalankan usahanya, maka peranan Notaris dalam kegiatan investasi sangat dibutuhkan melalui pembuktian tertulis. Studi ini bertujuan untuk menganalisa dan memberikan pemahaman peranan Notaris dalam mendukung investasi di Indonesia saat MEA diberlakukan. Penelitian menggunakan metode yuridis normatif. Hasil studi menunjukkan bahwa peran Notaris melalui investasi langsung yaitu berwenang membuat akta otentik yang
} 


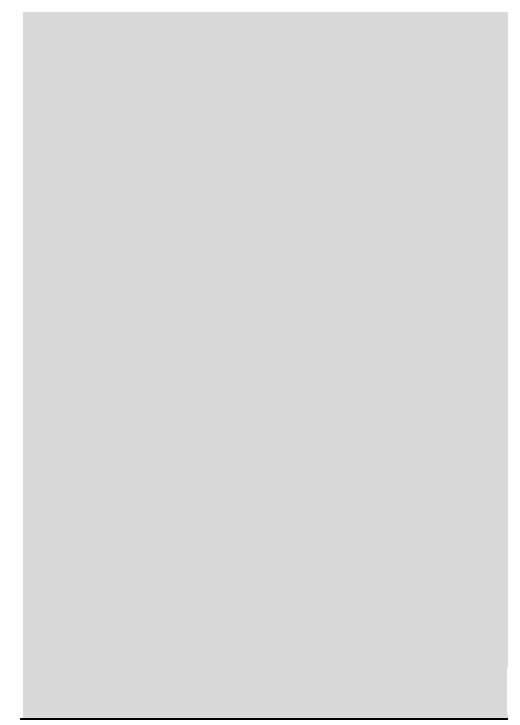

dilandasi dengan Undang-Undang Perseroan Terbatas. Selain itu, kewenangan Notaris diatur dalam Undang-Undang Jabatan Notaris dan Undang-Undang Jabatan Notaris Perubahan seperti: memberikan penyuluhan hukum, pelayanan dan melegalisasi dokumen publik yang akan digunakan di Indonesia atau diperlukan untuk investasi di luar negeri. Implikasi diberlakukannya MEA juga harus disadari oleh Notaris. Maka sebagai profesi hukum dalam memberikan pelayanan kepada masyarakat haruslah berbekal penguasaan Bahasa Inggris, penguasaan mengenai hukum investasi sesuai dengan hirarki perundang-undangan dan peningkatan kompetensi sesuai dengan Undang-Undang Jabatan Notaris dan Undang-Undang Jabatan Notaris Perubahan, Kode Etik Notaris, dan Anggaran Rumah Tangga I.N.I sehingga mampu bersaing secara profesionalitas.

\section{Pendahuluan}

Globalisasi dibidang ekonomi mengakibatkan meningkatnya kerjasama antar subjek hukum internasional. Upaya yang dilakukan dalam bidang ekonomi diantaranya dalam bentuk perdagangan maupun investasi guna mendapatkan keuntungan dari para pihak yang melakukan kerjasama internasional. Dampak globalisasi ekonomi tersebut semakin mendorong Indonesia sebagai anggota negara ASEAN untuk berperan aktif ditingkat internasional. Era Masyarakat Ekonomi ASEAN (MEA) merupakan integrasi berbagai ekonomi antar anggota negara dalam menghadapi perdagangan bebas antar negara-negara ASEAN tersebut. Dengan tujuan bahwa pembentukkan MEA untuk membuka cara pandang negara anggota ASEAN terhadap permasalahan dosmestik di kawasan ASEAN tanpa meninggalkan prinsip-psinrip dasar ASEAN. Karakteristik utama MEA diantaranya: (a) basis produksi dan pasar tunggal; (b) membangun kawasan ekonomi yang mampu bersaing; (c) pembangunan kawasan ekonomi secara merata; serta (d) kawasan yang terintegrasi penuh dengan ekonomi global. Karakteristik ini kemudian dicantumkan dalam satu Cetak Biru.

Deklarasi Cetak Biru Komunitas Ekonomi ASEAN menjelaskan bahwa MEA merupakan pasar tunggal berbasis produksi dari negara-negara di wilayah Asia Tenggara dengan tujuan untuk menghilangkan hambatan yang biasa dihadapi ketika melakukan kegiatan ekonomi antar negara. ${ }^{1}$ Pemberlakuan MEA dalam sektor investasi diharapkan dapat meningkatkan kegiatan investasi asing dan daya saing antar negara anggota ASEAN sebagai negara tujuan investasi di dunia. Implikasi tersebut membuktikan bahwa Indonesia masih menjadi salah satu tempat favorit bagi investor asing dalam menanamkan modalnya. ${ }^{2}$ Hal ini dikarenakan beberapa faktor

\footnotetext{
1 PUTRI AWWALLIN, D. H. I. K. A. (2015). PELUANG, TANTANGAN, DAN PROSPEK PERBANKAN SYARIAH INDONESIA DALAM MENGHADAPI PERSAINGAN MASYARAKAT EKONOMI ASEAN (MEA) 2015. JURNAL AKUNTANSI UNESA, 3(2).h 3.

2 Antique (2011) Indonesia Ladang Investasi Asing. Retrieved from https://www.viva.co.id/indepth/fokus/248658-indonesia-ladang-investasi-asing, diakses 8 Agustus 2019.
} 
yang mempengaruhi diantaranya: mendapatkan fasilitas dan insentif yang biasanya ditawarkan oleh host country, seperti insentif pajak, market baru masih mudah dicari, masih terdapat sumber daya/bahan mentah, harga buruh yang murah, lisensi dan transfer of technology serta status Indonesia menjadi salah satu negara yang telah meratifikasi perjanjian internasional terkait dengan investasi dan perdagangan internasional. Kebutuhan terhadap modal asing tidak dapat dihindari terutama bagi negara-negara berkembang karena mutlaknya arti penting pembangunan ekonomi bagi negara-negara tersebut.

Bagi Indonesia manfaat utama dalam sektor ekonomi ialah terbukanya jalur ekspor yang kerap kali menjadi hambatan bagi para ekportir sehingga dengan ini berharap dapat meningkatkan penghasilan Indonesia. ${ }^{3}$ Namun, sebaliknya Indonesia juga akan dihadapkan dengan gencarnya produk berupa barang maupun jasa yang berasal dari luar Indonesia sehingga para pengusaha lokal harus mampu bersaing dengan memiliki strategi dan berinovasi agar produknya masih tetap unggul. Di sektor jasa MEA juga memberikan dampak terhadap profesi Notaris dan PPAT yang bergerak dibidang hukum dalam ranah membuat akta perjanjian antar warga negara atau antar lembaga baik pemerintah maupun non pemerintah serta membuat akta yang berkaitan dengan hak atas tanah. Tentu secara langsung Notaris dan PPAT akan merasakan dampak ini karena akan kebanjiran klien. Seperti perjanjian kredit yang melibatkan perseorangan maupun korporasi yang membutuhkan dana untuk ekspansi bisnisnya ke dalam maupun diluar Indonesia.

Kebijakan Pemerintah Indonesia dalam bidang investasi diwujudkan dengan UndangUndang No. 25 Tahun 2007 tentang Penanaman Modal (untuk selanjutnya disebut dengan UU Penanaman Modal) dan Undang-Undang No. 8 Tahun 1995 tentang Pasar Modal (untuk selanjutnya disebut dengan UUPM). Selain memperhatikan kemudahaan berinvestasi, keuntungan yang maksimal juga keamanan menjadi sangat penting bagi investor dalam melakukan dan memilih jenis investasi. Berinvestasi juga dapat dilakukan di pasar modal oleh masyarakat baik bagi pemodal kecil dan menengah. UU Penanaman Modal menjelaskan bahwa kegiatan penanam modal asing dapat sepenuhnya maupun secara berpatungan dengan penanam modal dalam negeri menanamkan modalnya guna melakukan usaha di wilayah Negara Republik Indonesia dengan tunduk pada ketentuan hukum Indonesia. Penjelasan tersebut membuktikan bahwa Indonesia membuka dan memberi kesempatan terutamanya untuk investor asing menanamkan modalnya di Indonesia sesuai dengan hukum yang berlaku di Indonesia.

Melalui ketentuan tersebut maka jasa hukum Notaris juga sangat dibutuhkan dalam lalu lintas investasi di Indonesia. Notaris menjalankan tugasnya dalam menjalin dan mengesahkan hubungan hukum antara para pihak yang berkepentingan dalam menjalankan usahanya. Keterlibatan Notaris juga mendukung pemenuhan kebutuhan MEA akan pembuktian tertulis yang berhubungan dengan masyarakat dibidang ekonomi, perbankan, pertanahan, perdagangan, dan sosial baik ditingkat global, regional serta nasional. Yang akan mendukung kepentingan, menentukan kewajiban

\footnotetext{
${ }^{3}$ Ridwan, R. (2015). MARGIN APRESIASI HARMONISASI HUKUM INDONESIA DALAM PERSPEKTIF EMPAT PILAR ASEAN ECONOMIC COMMUNITY1. Supremasi Hukum: Jurnal Penelitian Hukum, 24(2), 179-191, h 189
} 
dan hak dari masing-masing pihak guna memberikan perlindungan, sesuai dengan ketertiban dan menjamin kepastian hukum sehingga sengketa dapat dihindari. ${ }^{4}$

Berdasarkan uraian diatas, menarik bagi penulis untuk mengulas bagaimana peran Notaris dalam mendukung investasi di Indonesia? Dan bagaimana kesiapan Notaris dalam menghadapi MEA? Penulisan artikel ini bertujuan untuk menganalisa peran Notaris dalam mendukung investasi sehingga keseimbangan hak dan kewajiban investor yang akan menanamkan modalnya di Indonesia dapat terlindungi dan memberikan pemahaman terhadap kesiapan Notaris dalam menghadapi MEA.

Terdahulu terdapat penelitian yang mengkaji masalah yang hampir serupa ialah Yudo Diharjo Lantanea yang melakukan studi tentang hubungan Notaris dengan Masyarakat Ekonomi ASEAN (MEA) dalam mendukung perdagangan dan perekonomian. ${ }^{5}$ Berikutnya, Linggar Pradiptasari, Akhmad Khisni yang melakukan studi tentang mengkaji praktek Pejabat Pembuat Akta Tanah (PPAT) dan Notaris yang berbasis Islam atau Notaris Syariah berdasarkan Al-Qur'an dan Sunatullah Nabi Muhammad dalam menghadapi Masyarakat Ekonomi ASEAN (MEA). ${ }^{6}$ Secara umum, kedua penelitian tersebut memiliki persamaan yakni berkaitan dengan Notaris dan Masyarakat Ekonomi ASEAN (MEA), walaupun masing-masing memiliki fokus penelitian yang berbeda. Sedangkan penelitian ini memiliki perbedaan yang mendasar dibandingkan dengan kedua penelitian yang sebelumnya ialah berfokus pada peranan dan kesiapan Notaris dalam lalu lintas investasi di Indonesia saat MEA diberlakukan.

\section{Metode Penelitian}

Artikel ini adalah penelitian yuridis normatif yang mengkaji peranan Notaris dari aspek hukum yang berlaku dalam mendukung investasi di Indonesia serta menganalisa kesiapan Notaris saat MEA diberlakukan. Dengan menggunakan pendekatan konsep (the konseptual approach) dan pendekatan perundang-undangan (the statute approach) bahwa UUJN dan/atau UUJN Perubahan merupakan dasar peranan Notaris dalam melaksanakan tugasnya didukung dengan peraturan lainnya serta meneliti konsep hukum terkait kesiapan Notaris dalam menghadapi MEA. Bahan hukum primer bersumber dari peraturan perundang-undangan, sedangkan bahan hukum sekunder bersumber dari buku-buku hukum, jurnal-jurnal hukum dan internet yang membahas permasalahan yang diajukan. Dilakukan sistem (card system) pada studi kepustakaan yang kemudian akan digunakan kartu kutipan setelah itu dicatat dan dikutip beserta sumbernya. Disajikan dengan teknik deskriptif yaitu menguraikan atau melukiskan apa adanya terhadap suatu hal. ${ }^{7}$

\footnotetext{
4 Lantanea, Y. D. (2017). DUKUNGAN NOTARIS DALAM PEREKONOMIAN DAN PERDAGANGAN DI ERA MASYARAKAT EKONOMI ASEAN (MEA). PROSIDING FAKULTAS HUKUM UPH MEDAN., h 54-55

${ }_{6}^{5}$ Ibid, h 54-69

6 Pradiptasari, L. (2017). Sinergitas Hukum Islam dengan Peranan Notaris dan Pejabat Pembuat Akta Tanah (PPAT) dalam Menghadapi Masyarakat Ekonomi ASEAN (MEA). Jurnal Akta, 4(4), 545-550. h 545-550

${ }^{7}$ Mezak, M. H. (2006). Jenis, Metode dan Pendekatan Dalam Penelitian Hukum. Law Review: Fakultas Hukum Universitas Harapan, 5 (3), h 88
} 


\section{Hasil Dan Pembahasan}

\subsection{Peran Notaris Dalam Mendukung Investasi di Indonesia}

Indonesia mengenal 2 (dua) bentuk investasi yang dapat dilakukan yaitu dengan cara investasi tidak langsung dan investasi langsung. ${ }^{8}$ Investasi tidak langsung artinya seseorang bertransaksi dengan menggunakan instrument surat berharga seperti obligasi dan saham di pasar modal. Investasi secara langsung dapat diartikan seseorang yang dalam melakukan investasi dengan cara mendirikan perusahaan baru, bekerjasama dengan mitra lokal, membeli sebagian/total saham atau yang dikenal dengan sebutan mengakuisisi perusahaan. Melalui cara tersebut peranan Notaris sangat dibutuhkan berdasarkan pada Undang-Undang No. 30 Tahun 2004 tentang Jabatan Notaris (untuk selanjutnya disebut dengan UUJN) dan Undang-Undang No. 2 Tahun 2014 tentang Perubahan Atas Undang-Undang No. 30 Tahun 2004 tentang Jabatan Notaris (untuk selanjutnya disebut dengan UUJN Perubahan).

Dalam menunjang investasi langsung, oleh UU Penanaman Modal dijelaskan dalam Pasal 5 ayat (2) bahwa perusahaan yang digunakan untuk berinvestasi tersebut harus berdasarkan hukum Indonesia dalam bentuk perseroan terbatas, yang dalam hal ini diatur dalam Undang-Undang No. 40 Tahun 2007 tentang Perseroan Terbatas (untuk selanjutnya disebut dengan UUPT). Notaris dalam jabatannya hanya membantu investor asing dalam pendirian perusahaan yang diinginkan. Sebagaimana ketentuan dalam Pasal 15 UUJN bahwa akta otentik merupakan produk kewenangan pejabat negara yaitu Notaris yang membuat semua perbuatan, penetapan, dan perjanjian, sepanjang pembuatan akta tersebut tidak ditugaskan atau dikecualikan kepada pejabat lain oleh peraturan umum.

Eksistensi Notaris melalui kewenangannya juga sangat jelas dalam Pasal 7 ayat (1) dan diperkuat dengan penjelasan Pasal 21 ayat (5) UUPT bahwa perubahan terhadap anggaran dasar dan data perseroan dimuat dan dinyatakan dalam akta notaris. Sehingga dapat disimpulkan bahwa akta notaris berfungsi sebagai media dari dan ke Menteri Hukum dan Hak Asasi Manusia guna mendapatkan pengesahan atas pendirian, persetujuan dan penerimaan pemberitahuan atas perubahan data perseroan ataupun perubahan anggaran dasar. Dan perkembangan saat ini dalam penyampaiannya Notaris diberikan kuasa oleh Direksi PT untuk mengajukan permohonan pemberitahuan, persetujuan dan pengesahan jika terdapat perubahan data akibat perubahan susunan pemegang saham karena adanya peralihan saham dan/atau perubahan jumah kepemilikan saham yang dimiliki ${ }^{9}$ melalui AHU Online.

Kewenangan lainnya selain berhubungan pembuatan akta, Notaris dalam Pasal 15 ayat (2) huruf e dan Pasal 16 ayat (1) huruf e UUJN juga berwenang memberikan pemahaman tentang hukum dan pelayanan dalam hal pendirian perusahaan asing, seperti:

1. Bidang usaha yang dipilih, berkaitan dengan adanya besaran presentase kepemilikan modal yang terbatas walaupun pada dasarnya semua bidang

\footnotetext{
${ }^{8}$ Lantu, I. G. (2010). Peranan notaris dalam perubahan perseroan terbatas non fasilitas menjadi penanaman modal asing (Doctoral dissertation, Universitas Indonesia. Fakultas Hukum)., h 5-6 ${ }^{9}$ YENNY, Y. (2016). Kewenangan Notaris dalam Penjualan Saham Perseroan Terbatas yang Pemegang Saham Merupakan Perusahaan Asing. Premise Law Journal, 2., h 16
} 
usaha terbuka bagi investor asing, sebagaimana yang tertuang dalam Perpres No. 44 Tahun 2016 tentang ketentuan Daftar Negatif Investasi.

2. Tempat kedudukan usaha, dibutuhkan untuk mendapatkan izin dan memberikan manfaat bagi masyarakat sekitar.

3. Identitas para pemegang saham, guna memperoleh kejelasan kewarganegaraan pendiri dan kepemilikan saham. Yang mana dapat dibuktikan dengan paspor, visa kerja bagi orang asing dan kartu tanda penduduk (KTP) bagi orang lokal (Indonesia).

4. Struktur organisasi, selain didasarkan pada ketentuan UUPT juga diatur didalam Perpres No. 20 Tahun 2018 terdapat pengecualian kedudukan direktur personalia dilarang diduduki oleh tenaga kerja asing.

Dibukanya kesempatan investasi melalui MEA, akan berimbas pada semakin banyaknya investor yang ingin mendirikan perusahaan asing di Indonesia. Maka kaitan antara kewenangan Notaris dengan dibukanya investasi di era MEA adalah menjadi kesempatan bagi Notaris. Sebagai jabatan yang diberikan kewenangan dalam membuat akta otentik, Notaris juga berwenang untuk memberikan pemahaman/penyuluhan hukum terkait penanaman modal, bisnis, perjanjian privat yang dikehendaki oleh para pihak agar selaras dengan aturan yang berlaku, maupun kegiatan sosial yang mungkin saja akan dilakukan oleh investor asing. ${ }^{10}$ Peran Notaris dalam aktivitas pasar modal sebagai profesi yang mendukung investasi yaitu berwenang dalam penyusunan anggaran rumah tangga (AD/ART) atau anggaran dasar dari pihak atau pelaku pasar modal kedalam bentuk akta otentik, seperti perusahaan public, emiten, perusahaan efek, serta kontrak-kontrak penting seperti kontrak investasi kolektif, perjanjian penunjukan konsultan hukum, pembuatan akta seperti akta perwaliamanatan, akta perjanjian penjaminan emiten efek, serta akta yang berkaitan dengan merger, akuisisi dan konsolidasai perusahaan. Atas kewenangan yang diberikan maka seorang Notaris dalam menjalankan profesinya haruslah dilandasi asas kehati-hatian saat memeriksa dokumen yang menjadi persyaratan dari perbuatan hukum yang akan dilakukan oleh para pihak, yang dalam hal ini adalah investor asing. Karena Notaris tidak bertanggung jawab terhadap pelaksanaan ataupun operasional pasca pendirian perusahaan asing tersebut. Namun, Notaris dapat dimintai pertanggungjawaban baik secara perdata dan administrasi sepanjang berkaitan dengan akta yang dibuatnya. ${ }^{11}$

Seiring perkembangan saat ini membeli seluruhnya atau sebagian saham perusahaan yang telah bergerak dibidang penanaman modal menjadi pilihan investor asing. Cara akuisisi ini dipilih mengingat adanya beberapa faktor, salah satunya terdapat bidang usaha yang tidak diperkenankan melakukan investasi dan diwajibkan melakukan kerjasama dengan modal domestik. Oleh karenanya kewenangan Notaris dalam bentuk otentisitas dokumen pemberian persetujuan pemindahan hak atas saham oleh organ perseroan sangat dibutuhkan. Bentuk persetujuan yang dimaksud, ialah:

a. Notulen RUPS, Pasal 90 UUPT menjelaskan risalah dapat dicatat tanpa Notaris yang disebut notulen dan pencatatan yang menghadirkan Notaris yang akan

\footnotetext{
${ }^{10}$ Lantanea, Y. D, Op cit, h 68

${ }^{11}$ Sjaifurrachman, \& Adjie, H. (2011). Aspek pertanggungjawaban notaris dalam pembuatan akta. Mandar Maju., h 173
} 
menghasilkan Berita Acara Rapat Umum Pemegang Saham (RUPS). Namun, adakalanya terdapat keputusan RUPS yang dinyatakan dibawah tangan mengisyaratkan harus dinyatakan dalam akta notaris. Maka yang diberi kuasa menyatakan apa yang terjadi, dibicarakan dan diputuskan dalam rapat tersebut dihadapan Notaris. Dari penjelasan tersebut maka Notaris akan membuat akta yang diberi nama Akta Pernyataan Keputusan Rapat (PKR).

b. Surat Pernyataan dari setiap pemegang saham berdasarkan Circular Resulation, bahwa pengambilan keputusan dapat dilakukan tanpa bertatap muka sebagaimana disebutkan dalam Pasal 91 UUPT. Sehingga secara tertulis hasil keputusan tersebut diedarkan kepada para pemegang saham oleh direksi. Yang kemudian oleh Notaris dicatatkan dan didaftarkan dalam buku khusus (waarmeking).

Sejak adanya Peraturan Pemerintah terbaru No. 24 Tahun 2018 tentang Pelayanan Perizinan Berusaha Terintegrasi secara Elektronik atau Online Single Submission (OSS) mensyaratkan investor untuk mendaftarkan perusahaan secara online baik bagi investor yang membuka usaha dengan perusahaan baru, mengembangkan usaha, memperpanjang izin, mengubah dan/atau memperbaharui data perusahaan bila perusahaannya sudah berdiri. Maka saat ini syarat pendirian perusahaan asing tidak memerlukan izin prinsip dari Badan Koordinasi Penanaman Modal (BKPM). Hal ini membuat banyak investor belum memahami mekanisme yang jelas. Peran Notaris dalam penyesuaiannya terhadap OSS atas kuasa yang diberikan kepadanya adalah memberikan pemahaman dan membantu para pemegang saham.

Dukungan Notaris dalam peningkatan investasi asing guna merealisasikan pelaksanaan MEA juga dilakukan dengan melegalisasi dokumen-dokumen publik yang berasal dari luar negeri agar dapat digunakan di wilayah hukum suatu negara. ${ }^{12}$ dalam kegiatan investasi dokumen yang perlu dilegalisasi, diantaranya:

a. Struktur pemegang saham dalam bentuk akta anggaran dasar perusahaan dan/atau pendirian perusahaan diluar negeri, negeri tempat investasi dilakukan;

b. Surat pernyataan penunjukkan seorang kuasa yang mewakili perusahaan tersebut dalam mengurus pendaftaran dan pendirian perusahaan di negara tempat dilakukannya investasi;

c. Serta akta-akta notaris yang berhubungan dengan kegiatan investasi yang diterbitkan di luar negeri.

Wewenang Notaris dalam melakukan legalisasi terhadap dokumen asli sebagaimana dilakukan oleh pengadilan, dapat dilakukan dengan bentuk pengesahaan kecocokan fotocopy dengan surat aslinya sesuai dengan Pasal 15 ayat (2) huruf d UUJN Perubahan. Legalisasi di Pasal 15 ayat (2) huruf a UUJN Perubahan adalah Notaris mengesahkan tanda tangan yang dibuat dan dinyatakan sendiri oleh para pihak maupun perseroangan, dengan bermeterai cukup, kemudian oleh Notaris didaftarkan ke dalam buku khusus legalisasi. Dan otentisitas Notaris dalam memberikan tanda tangan berkaitan erat dengan legalisasi dokumen oleh Kementrian Hukum dan Hak

12 Makarim, E. (2015). Keautentikan Dokumen Publik Elektronik Dalam Administrasi Pemerintahan Dan Pelayanan Publik. Jurnal Hukum \& Pembangunan, 45(4), 508-570. h 547 
Asasi Manusia sebelum dibawa ke luar negeri sehingga mewajibkan Notaris mengirimkan contoh specimen tandatangannya sebagaimana ketentuan Pasal 7 huruf c UUJN Perubahan.

\subsection{Kesiapan Notaris Dalam Menghadapi Masyarakat Ekonomi ASEAN (MEA)}

Aktivitas ekonomi dalam perdagangan internasional mempengaruhi peranan dalam sektor jasa, khususnya konsultan asing di Indonesia, diantaranya: 1) dapat diperdagangkannya kebutuhan jasa membuat skala ekonomi menciptakan keuntungan melalui spesialisasi dari perdagangan jasa, 2) kebutuhan pemasok bisnis jasa meningkat akibat pertumbuhan perusahaan multinasional (multinational corporation) yang meningkat, 3) perubahan metode/cara berproduksi yang serba otomatis sehingga kebutuhan akan jasa semakin penting, 4) teknologi komunikasi dan pemrosesan data yang serba modern (modern data processing). Melihat keempat faktor tersebut, konsultan hukum Indonesia tidak boleh tertinggal melainkan harus meningkatkan kinerja sebagai dampak dibukanya liberalisasi MEA. ${ }^{13}$ Bahwa tujuan dari liberalisasi jasa ini guna menghilangkan hambatan penyedian ataupun pendirian jasa lintas negara di kawasan ASEAN namun tetap tunduk pada regulasi domestik.

Pada tanggal 19 November 2007 negara anggota ASEAN sepakat menadatangani MRA (Mutual Recognition Agreement). Melalui Departemen Perdagangan terdapat 7 intial offer sebagai upaya pemerintah mendukung perpindahan tenaga kerja terampil, diantaranya (1) jasa perawatan; (2) praktisi gigi/dokter gigi; (3) praktisi medis; (4) jasa akuntan; (5) penyigian (surveying); (6) jasa teknik; (7) arsitek. Meskipun sementara ini profesi Notaris belum ditetapkan sebagai profesi yang dapat lintas ASEAN akan tetapi dampak tidak langsung dari MEA bagi Notaris adalah kebanjiran klien terutama dalam perjanjan kredit perseorangan maupun korporasi yang membutuhkan dana untuk ekpansi bisnisnya baik ke dalam mapun ke luar Indonesia. Hal ini terjadi karena amanat Pasal 17 huruf a UUJN Perubahan bahwa Notaris memiliki kewenangan diwilayah jabatannya yaitu seluruh wilayah provinsi dari tempat kedudukannya, dan hanya berkedudukan di satu tempat dikota/kabupaten. Sebagai contoh seorang Notaris tidak dapat membuka praktik atau membuat akta otentik di wilayah Nusa Tenggara Barat (provinsi adalah batas yuridiksi), jika ia memiliki wilayah kerja di Bali. Maka akta yang dibuat diluar wilayah jabatannya hanya berkedudukan seperti akta dibawah tangan.14 Namun tidak menutup kemungkinan dalam MRA (Mutual Recognition Agreement) kedepannya profesi Notaris ditambahkan. ${ }^{15}$

Implikasi diberlakukannya MEA juga harus disadari bagi Notaris karena akan berdampak pada banyaknya klien yang membutuhkan jasanya. Di era MEA yang sudah berlangsung sejak 2015, membuat Notaris harus berbenah yaitu pertama, kemampuan bahasa inggris secara aktif. Karena bahasa inggris berperan sebagai media komunikasi dan interaksi secara global seiring dengan kemajuan dan persaingan globalisasi sehingga kesalahpahaman saat berkomunikasi kepada klien dapat

\footnotetext{
${ }^{13}$ Delarosa, S. (2016). Liberalisasi Fee Advokat: Antara Perlindungan Dan Kompetisi Terhadap Advokat Indonesia. Veritas et Justitia, 2(2), 355-379. h 358

14 Saputra, A. F. (2016). Larangan Pembuatan Akta Notaris Diluar Wilayah Jabatan Notaris. Universitas Narotama, Surabaya., h 3

${ }^{15}$ Pradiptasari, L. (2017). Op Cit, h 546
} 
dihindari. Kedua, Notaris memahami dan menguasai hirarki peraturan perundangundangan yang berhubungan dengan investasi, pasar modal dan penanaman modal, sehingga Notaris memiliki skill lebih dalam melakukan kegiatan pengurusan perusahaan asing. Ketiga yang paling terpenting adalah lebih mencermati UUJN dan/atau UUJN Perubahan, Kode Etik Notaris, dan Anggaran rumah Tangga Ikatan Notaris Indonesia (I.N.I) sebagai bagian dari peningkatan kompetensi seorang Notaris.

Sebagaimana oleh Negara secara atribusi memberikan kewenangan kepada Notaris sebagai pejabat umum yang diangkat oleh Penguasa Umum (Menteri Hukum dan HAM). Kewenangan yang dimaksud dalam Pasal 1 ayat 1 UUJN Perubahan adalah membuat semua perjanjian, perbuatan, dan penetapan dalam bentuk akta otentik sesuai dengan peraturan umum, dan yang oleh berkepentingan, menyimpan aktanya dan grosse, salinan dan kutipannya, menjamin kepastian tanggal, sepanjang tidak ditugaskan pada pejabat atau orang lain. Maka kewenangan eksklusif tersebut menempatkan kedudukan Notaris menjadi sangat penting dalam kehidupan hukum. Sehingga pelayanan jasa yang diberikan oleh Notaris benar-benar memiliki bobot dan nilai yang dapat diandalkan.

Kesiapan dalam menyelesaikan berbagai persoalan hukum para pihak yang berpentingan dan persaingan dengan tenaga kerja asing merupakan tantangan yang yang dihadapi Notaris saat ini. Kesiapan dalam menghadapi dan menyelesaikan berbagai persoalan sehubungan dengan semakin kompleksnya keperluan hukum para pihak yang berkepentingan membuat kebutuhan akan kepastian serta perlindungan hukum lewat akta otentik semakin mendesak. Notaris yang merupakan jabatan kepercayaan yang terhormat (officium nobile) diberikan oleh Negara kepadanya haruslah melekat profesionalitas (mutu keilmuannya) yang memadai. Terutama yang berkenaan dengan substansi yang diperjanjikan dan diatur dalam akta, seperti: aspek hukum agraria, hukum perdata dan hukum dagang. Serta integritas moral yang baik dalam menjalankan profesi hukumnya. Karena dampak dari pertumbuhan dan keterbukaan pasar membuat kebutuhan akan pelayanan, perlindungan serta kepastian hukum kepada masyarakat lewat akta otentik sangat dibutuhkan. Mengingat akta otentik merupakan produk hukum yang dihasilkan Notaris sebagai alat bukti yang sah. ${ }^{16}$

\section{Kesimpulan}

Peranan Notaris dalam investasi di Indonesia melalui pasar modal maupun secara langsung melalui pendirian perusahaan yaitu sesuai kewenangannya dalam membuat akta otentik. Sebagaimana dijelaskan dalam ketentuan Pasal 15 UUJN Perubahan dan diperkuat dengan Pasal 7 ayat (1) dan penjelasan Pasal 21 ayat (5) UUPT. Notaris juga diberikan kuasa oleh pendiri untuk mengajukan permohonan pengesahan, persetujuan, dan pemberitahuan ke Menteri melalui AHU Online dan pelayanan terkait sistem OSS. Selain pendirian perusahaan, otentisitas dokumen berkaitan dengan pengalihan hak atas saham juga menjadi kewenangan Notaris mengingat saat ini investor lebih memilih dengan cara akuisisi. Pasal 15 ayat (2) huruf e dan Pasal 16

16 Putra, N.N (2016) Ini Bekal yang Wajib Notaris Miliki Saat Hadapi MEA. Retrieved from https://www.hukumonline.com/berita/baca/lt5742bea10d729/ini-bekal-yang-wajib-notarismiliki-saat-hadapi-mea/, diakses 18 Juli 2019. 
ayat (1) huruf e UUJN Perubahan menentukan bahwa Notaris dapat memberikan penyuluhan hukum dan pelayanan, seperti: bidang usaha yang dipilih, tempat kedudukan usaha, identitas pera pemegang saham, dan struktur organisasi. Notaris dibidang investasi dalam merealisasikan MEA diberi wewenang dalam melegalisasi dokumen publik yang akan dipergunakan di Indonesia dan/atau yang diperlukan untuk berinvestasi diluar negeri. Bentuk legalisasi dalam Pasal 15 ayat (2) huruf a dan d UUJN Perubahan yang dimaksud dapat berupa mencocokkan dengan fotocopynya dan/atau mengesahkan dan didaftarkan ke dalam buku khusus legalisasi.

Walaupun di ketentuan MRA (Mutual recognition Agreement) Notaris belum ditetapkan yang dapat lintas ASEAN. Tetapi tidak menutup kemungkinan kedepannya profesi Notaris ditambahkan. Bagi Notaris sangat perlu disadari bahwa implikasi pemberlakuan MEA akan berdampak pada kebutuhan akan jasanya. Maka dari itu Notaris harus berbekal kemampuan Bahasa inggris, penguasaan hukum investasi, peningkatan kompetensi notaris dengan mencermati UUJN, UUJN Perubahan, Kode Etik Notaris, serta Anggaran Rumah Tangga I.N.I. Selain itu Notaris juga harus mau memperkaya diri dari sisi pengetahuan, keterampilan dan berperilaku yang baik sehingga nantinya dapat bersaing secara profesionalitas.

\section{Daftar Pustaka / Daftar Referensi}

Buku

Mezak, M. H. (2006). Jenis, Metode dan Pendekatan Dalam Penelitian Hukum. Law Review: Fakultas Hukum Universitas Harapan, 5 (3).

Sjaifurrachman, \& Adjie, H. (2011). Aspek pertanggungjawaban notaris dalam pembuatan akta. Mandar Maju.

\section{Jurnal}

Delarosa, S. (2016). Liberalisasi Fee Advokat: Antara Perlindungan Dan Kompetisi Terhadap Advokat Indonesia. Veritas et Justitia, 2(2), 355-379.

Lantanea, Y. D. (2017). DUKUNGAN NOTARIS DALAM PEREKONOMIAN DAN PERDAGANGAN DI ERA MASYARAKAT EKONOMI ASEAN (MEA). PROSIDING FAKULTAS HUKUM UPH MEDAN.

Makarim, E. (2015). Keautentikan Dokumen Publik Elektronik Dalam Administrasi Pemerintahan Dan Pelayanan Publik. Jurnal Hukum \& Pembangunan, 45(4), 508570.

PUTRI AWWALLIN, D. H. I. K. A. (2015). PELUANG, TANTANGAN, DAN PROSPEK PERBANKAN SYARIAH INDONESIA DALAM MENGHADAPI PERSAINGAN MASYARAKAT EKONOMI ASEAN (MEA) 2015. JURNAL AKUNTANSI UNESA, 3(2).

Pradiptasari, L. (2017). Sinergitas Hukum Islam dengan Peranan Notaris dan Pejabat Pembuat Akta Tanah (PPAT) dalam Menghadapi Masyarakat Ekonomi ASEAN (MEA). Jurnal Akta, 4(4), 545-550.

Ridwan, R. (2015). MARGIN APRESIASI HARMONISASI HUKUM INDONESIA DALAM PERSPEKTIF EMPAT PILAR ASEAN ECONOMIC COMMUNITY1. Supremasi Hukum: Jurnal Penelitian Hukum, 24(2), 179-191. 
Saputra, A. F. (2016). Larangan Pembuatan Akta Notaris Diluar Wilayah Jabatan Notaris. Universitas Narotama, Surabaya.

YENNY, Y. (2016). Kewenangan Notaris dalam Penjualan Saham Perseroan Terbatas yang Pemegang Saham Merupakan Perusahaan Asing. Premise Law Journal, 2.

\section{$\underline{\text { Tesis }}$}

Lantu, I. G. (2010). Peranan notaris dalam perubahan perseroan terbatas non fasilitas menjadi penanaman modal asing (Doctoral dissertation, Universitas Indonesia. Fakultas Hukum).

\section{Online/World Wide Web}

Antique (2011) Indonesia Ladang Investasi Asing. Retrieved from https:// www.viva.co.id/indepth/fokus/248658-indonesia-ladang-investasiasing, diakses 8 Agustus 2019.

Putra, N.N (2016) Ini Bekal yang Wajib Notaris Miliki Saat Hadapi MEA. Retrieved from https://www.hukumonline.com/berita/baca/lt5742bea10d729/ini-bekalyang-wajib-notaris-miliki-saat-hadapi-mea/, diakses 18 Juli 2019. 